\title{
Phylogeography of the neon damselfish Pomacentrus coelestis indicates a cryptic species and different species origins in the West Pacific Ocean
}

\author{
S. Y. V. Liu $^{1, *}$, C. F. Dai ${ }^{1}$, G. R. Allen ${ }^{2}$, M. V. Erdmann ${ }^{3}$ \\ ${ }^{1}$ Institute of Oceanography, National Taiwan University, Taipei 10617, Taiwan, ROC \\ ${ }^{2}$ Department of Aquatic Zoology, Western Australian Museum, Locked Bag 49, Welshpool DC, Perth 6986, Australia \\ ${ }^{3}$ Conservation International, Indonesia Marine Program Jl. Drive Muwardi No. 17, Bali, Indonesia
}

\begin{abstract}
While the center of the world's marine biodiversity is undoubtedly the central West Pacific, the mechanisms by which such high biodiversity was generated and perpetuated are still under debate. In this study, we amplified both a mitochondrial DNA control region and 4 microsatellite loci to elucidate the historical phylogeography of the neon damselfish Pomacentrus coelestis in the West Pacific and used the distribution of alleles to test the 'Center of Origin' hypothesis. Two deeply divergent clades ('Pacific' and 'Micronesia') were identified, and the results of hierarchical analysis of molecular variance (proportion of variations among regions, $\Phi_{\mathrm{CT}}=0.752, \mathrm{p}<0.01$ ) and Bayesian assignments of genotypic data suggest a major genetic break between these clades. Demographic parameters, Tajima's $D$ and Fu's Fs values, also indicate that these 2 lineages have different historical trajectories, indicative of the existence of more than 1 species within the complex currently assigned to $P$. coelestis. To avoid misinterpretation of past dispersal inferences, these 2 lineages were analyzed separately, and the Pacific clade was found to lack a distinct dispersal direction, probably due to rapid population expansion in the past. In contrast, the Micronesian clade showed a northeastwardly cladogenesis. Additionally, mixed lineages were found in the Raja Ampat Islands, suggesting that the Micronesian clade fits not only with the prediction of the Center of Origin hypothesis, but also the 'Center of Overlap' hypothesis. Our results suggest that multiple evolutionary processes may have acted on single species, either simultaneously or at different times, and have important implications for reef fish management in the West Pacific.
\end{abstract}

KEY WORDS: Microsatellite $\cdot$ mtDNA $\cdot$ Management unit

\section{INTRODUCTION}

The central West Pacific is characterized by the world's highest marine biodiversity and includes the Philippines and Indo-Malay Archipelagos (Veron 2000, Roberts et al. 2002, Allen 2008). Species diversity peaks in this region and gradually attenuates with increased distance from its center (Bellwood \& Wainwright 2002, Paulay \& Meyer 2002, Connolly et al. 2003, Allen 2008). Understanding the processes that generate and maintain species diversity in this region is crucial for both marine biogeography and conservation (Palumbi 1994, Rocha \& Bowen 2008). 
A number of hypotheses have been proposed to explain the biogeographic patterns found in the central West Pacific. The 'Center of Origin' hypothesis proposes that species evolved in the central West Pacific and then dispersed toward peripheral areas (Ekman 1953), and Pleistocene vicariance events might have played an important role in the speciation of marine taxa (Mora et al. 2003). The 'Center of Accumulation' hypothesis suggests that speciation occurs mainly in peripheral regions, with subsequent larval transport eventually resulting in the accumulation of species in the central West Pacific (Rosen 1988). The 'Center of Overlap' hypothesis suggests that the overlap of adjacent biogeographic regions or tectonic plates contributes to the high biodiversity of this region (Woodland 1983). These 3 hypotheses have been tested by the species distribution patterns of many marine taxa (Paulay 1996, Bellwood \& Wainwright 2002, Paulay \& Meyer 2002, Connolly et al. 2003, Allen 2008). However, using present species range data to test these hypotheses is potentially problematic because distribution patterns may change over time (Holt 2003). Neutral genetic markers provide an alternative method for tracking the origin and dispersal patterns of marine taxa (Palumbi 1996, Hellberg et al. 2002).

By comparing the distribution of alleles of widespread species, we can make inferences about the origin of biodiversity based on allele divergence time. The Center of Origin hypothesis predicts that the oldest allele or clade will occur in the central West Pacific and that the younger clades will be located in the peripheral regions. In contrast, the Center of Accumulation hypothesis predicts that the oldest allele or clade will occur in peripheral localities and that younger alleles or clades occur in the central West Pacific. The Center of Overlap suggests that populations in the central West Pacific would be polyphyletic, harboring mixed lineages of different biogeographic demes (Palumbi 1996). Several phylogeographic studies of marine taxa have been conducted to test these hypotheses (Teske et al. 2005, Barber et al. 2006, Williams 2007, Drew \& Barber 2009, Malay \& Paulay 2010). However, the results were diverse and inconsistent, possibly due to variation in the biological and ecological characteristics of the different target species of each study.

The existence of cryptic lineages has been suggested to be common in marine environments (Knowlton 1993, 2000, Rocha \& Bowen 2008). These cryptic lineages often represent previously undis- cernible species. In the family Pomacentridae, many species with broad distributions have cryptic lineages in different geographic areas (Drew et al. 2008, 2010, Steinke et al. 2009). Pomacentrus coelestis Jordan \& Starks, 1901 (type locality: Wakanoura, Japan), commonly known as the neon damselfish, is widely distributed in the West Pacific, usually inhabiting seaward reefs among rubble beds (Allen 1991). Larvae remain in the plankton for approximately 19.5 d (Thresher et al. 1989), resulting in potentially high dispersal from their natal reefs. Marine planktonic larvae sometimes remain in close proximity to the original spawning grounds due to olfactory cues (Gerlach et al. 2007), habitat preference (Doherty et al. 1996), and swimming capabilities during the late larval stage (Fisher 2005). These characteristics suggest that many marine organisms with planktonic dispersal may have significant potential for local self-recruitment, which might reinforce genetic divergence of $P$. coelestis populations between Taiwan and mainland Japan (Liu et al. 2008). Therefore, we might expect to see a sequential cladogenesis with cryptic lineages by constructing phylogeographic relationships between populations. In the present study, we compared the genetic diversity of $P$. coelestis populations across the West Pacific (Indonesia, Brunei, Taiwan, Japan, Micronesia, Fiji, and Australia) to test the hypotheses related to the origin of Indo-Pacific biodiversity and to shed light on this species' phylogeographic distribution, historical demography, and potential for harboring cryptic lineages.

\section{MATERIALS AND METHODS}

Samples of Pomacentrus coelestis were collected with barrier and hand nets or small spears while scuba diving at 15 localities throughout the western Pacific (Fig. 1). Sample sizes ranged from 1 to 25 individuals (see Table 1), and all samples were preserved in $95 \%$ ethanol. The DNA extraction method was modified from Liu et al. (2005), in that the tissue sample was incubated at $55^{\circ} \mathrm{C}$ for $4 \mathrm{~h}$ in extraction buffer with Proteinase $\mathrm{K}$ (final concentration of $0.1 \mathrm{mg} \mathrm{ml}^{-1}$ ) instead of overnight.

\section{mtDNA control region}

In total, 140 individuals from 15 localities were analyzed. The partial mitochondrial control region was amplified using the universal primers CR-A and 


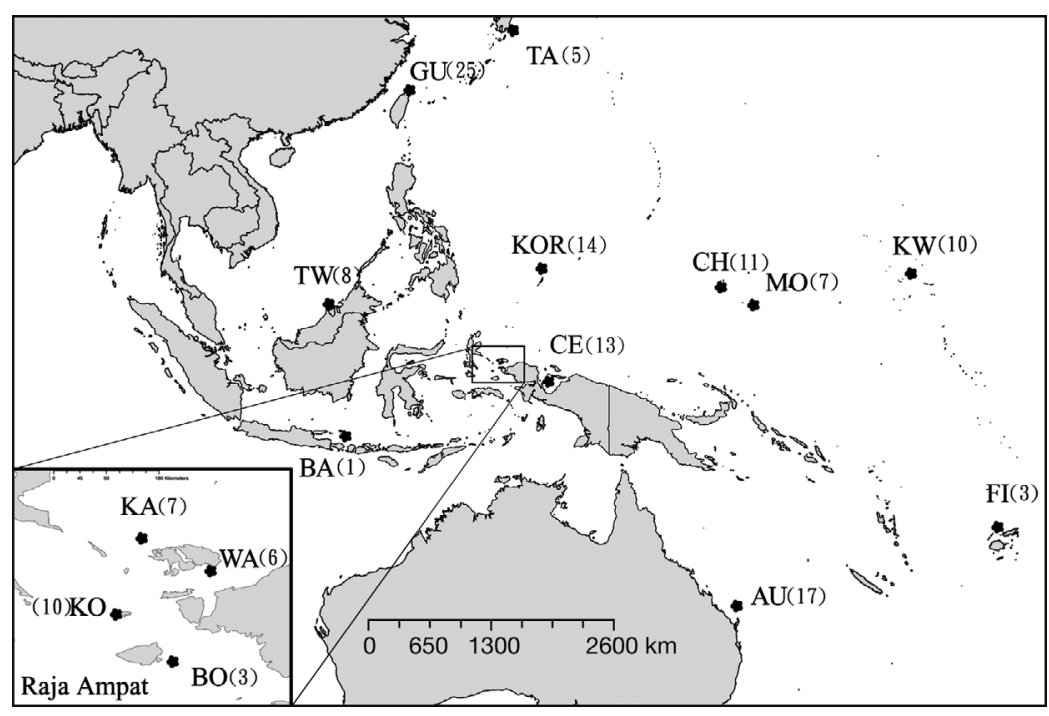

Fig. 1. Pomacentrus coelestis. Localities sampled in the West Pacific. Abbreviations are defined in Table 1 . The sample size of each locality is indicated by the number in parentheses

CR-E (Lee et al. 1995). Each $25 \mu \mathrm{l}$ reaction contained 10 to 50 ng DNA, $10 \mathrm{mM}$ Tris $\mathrm{HCl}(\mathrm{pH} 8.3), 50 \mathrm{mM}$ $\mathrm{KCl}, 1.5 \mathrm{mM} \mathrm{MgCl}_{2}, 1 \mathrm{U}$ Taq DNA polymerase (MDbio), $0.2 \mathrm{mM}$ dNTPs, and $0.3 \mathrm{mM}$ of each primer. The mixture was amplified with a cycling profile of $2 \mathrm{~min}$ at $94^{\circ} \mathrm{C}$ for the first cycle, followed by 34 cycles at $95^{\circ} \mathrm{C}(30 \mathrm{~s}), 50^{\circ} \mathrm{C}(30 \mathrm{~s})$, and $70^{\circ} \mathrm{C}(40 \mathrm{~s})$. The nucleotide sequences of the PCR products were determined using an ABI 377 automated sequencer. The sequences obtained in this study were submitted to GenBank (accession numbers JF314773-JF314842).

\section{Microsatellite loci}

The same samples as for mtDNA analysis were used to perform microsatellite genotyping except those from Bali $(\mathrm{n}=1)$ and Waigeo Island $(\mathrm{n}=6)$, which failed to amplify due to poor DNA quality. Four microsatellite loci were used, including POM3, POM6, POM25 (Miller-Sims et al. 2005), and AC1578 (Liu et al. 2007). In each PCR, we used $25 \mathrm{ng}$ of each primer, 1.5 to $3 \mathrm{mM} \mathrm{MgCl} 2,1 \times \mathrm{PCR}$ buffer, $0.2 \mathrm{mM}$ dNTPs, 1 U Taq DNA polymerase, and 2 to $5 \mathrm{ng}$ DNA in a $25 \mu \mathrm{l}$ reaction. Primers were labeled with the fluorescent dyes FAM and HEX, and PCR products were visualized and sized by automated detection with gel electrophoresis using an ABI3700 automated sequencer according to the manufacturer's recommendations. Peaks were analyzed by Peak Scanner Software 1.0 (Applied Biosystems).

\section{Data analysis}

mtDNA control region

Sequences were aligned using CLUSTAL W (Thompson et al. 1994), followed by manual editing with Sequencher 4.2 (Gene Codes). Data were analyzed by Arlequin 3.0 (Excoffier et al. 2005). Unique haplotypes were quantified, genetic diversity of populations was calculated, analysis of molecular variance (AMOVA; Excoffier et al. 1992) was performed, and a minimum spanning tree was generated by Arlequin 3.0. The Internetbased FindModel (www.hiv.lanl.gov/ content/sequence/findmodel/findmodel .html) was used to determine the optimal substitution model for the mtDNA control region.

A neighbor-joining (NJ) tree was constructed with MEGA 4 (Tamura et al. 2007) based on the optimal substitution model (Tamura-Nei plus Gamma), and the Gamma value was generated by FindModel Online (Gamma $=0.2883)$. Two Pomacentrus moluccensis sequences from the NCBI database (gi255743157 and gi255743156) were utilized as outgroups. Bootstrap values for an NJ tree were estimated using 1000 replicates. Additionally, Bayesian phylogenetic reconstructions were created with MrBayes 3.12 (Ronquist \& Huelsenbeck 2003). Subsequently, we established 2 duplicate runs of 3 heated and 1 cold Markov chain Monte Carlo (MCMC) chains, which started from a random tree and ran for 1000000 generations. We sampled trees every 100 generations, and a consensus tree was built from all trees with the exclusion of the first $25 \%$ of sampled trees to allow for sufficient burn-in. Posterior probabilities were determined by constructing a $50 \%$ majority-rule tree of all sampled trees.

The haplotype diversity (h), nucleotide diversity $(\pi)$, and their standard errors were estimated. The fixation index $\left(\Phi_{\mathrm{ST}}\right)$ was estimated based on the T92 plus Gamma model (Gamma $=0.1767$ ), and the significance of the $F$ statistics for population comparisons was assessed using 1000 permutations. AMOVA was used to estimate $\Phi$ statistics, which incorporate information on nucleotide differences between haplotypes. Hence, the proportions of variations among regions $\left(\Phi_{\mathrm{CT}}\right)$, among populations within regions $\left(\Phi_{\mathrm{SC}}\right)$, and within populations $\left(\Phi_{\mathrm{ST}}\right)$, were estimated. Random permutations of sequences among populations 
were evaluated to determine their significance. This hierarchical test can be used to reveal the degree of population subdivision in 2 scenarios. In Scenario A, populations were divided into 4 groups (West Pacific, Micronesia, West Papua, and South Pacific) to test their geographic partitioning. In Scenario B, populations were grouped based on their relationships in the phylogenetic tree. In addition, we used MIGRATE 3.1.3 (Beerli \& Felsenstein 2001) to estimate the past larval exchange among regions by considering divergence and gene flow between populations. A Bayesian search strategy (Beerli 2006) was used with 3 replicates of 4 chains, each running for 1000000 generations, with default heating temperatures. Samples were analyzed as the groupings used in AMOVA Scenario A, with Cenderawasih Bay (CE) extracted from the West Papua group as an independent group due to its isolated geographic history (Allen \& Erdmann 2006).

In addition, a pairwise mismatch distribution, comprised of the pairwise differences between all haplotypes, was performed for the historical demographic test in samples of 2 major clades, based on the deep divergence in the $\mathrm{NJ}$ and minimum spanning trees. The distribution is usually multimodal when the data comply with a demographic equilibrium. By contrast, a unimodal distribution may indicate recent demographic expansion (Slatkin \& Hudson 1991). Furthermore, Tajima's $D$ (Fu \& Li 1993) and Fu's Fs (Fu 1996) tests were used to test for departures from mutationdrift equilibrium and to examine the historical demography of Pomacentrus coelestis populations. The neutrality test was applied to examine deviations of Tajima's $D$ and Fu's Fs values from a neutral state. In addition, the population expansion parameter, Tau $(\tau)$, was used to estimate the time $(\mathrm{T})$ since population expansion, where $\mathrm{T}=\tau / 2 \mu$ and $\mu$ is the mutation rate (Gaggiotti \& Excoffier 2000).

\section{Microsatellite loci}

Samples were divided into 3 groups based on mtDNA haplotype distributions (see Fig. 3a). The Raja Ampat group contained individuals from 4 sites in the Raja Ampat area where the mixed lineages were found. Those individuals containing mtDNA haplotypes found in the Micronesian clade were grouped in the Micronesia group. Lastly, the Pacific group contained mtDNA haplotypes found in the Pacific clade. Allele frequencies, mean allelic richness, expected $\left(H_{\mathrm{e}}\right)$ and observed $\left(H_{\mathrm{o}}\right)$ heterozygosity per locus, and a linkage disequilibrium test with 1000 permutations between all pairs of loci were computed by Arlequin 3.0 (Excoffier et al. 2005). The Hardy-Weinberg expectations for each locus and population were tested by the Markov-chain method with GENEPOP version 3.3 (Raymond \& Rousset 1995; available at http://genepop.curtin.edu.au/), which implements Fisher's exact tests for multiple alleles (Guo \& Thompson 1992). The Bayesian analysis program STRUCTURE 2.3 (Pritchard et al. 2000) was used to infer population structure and to calculate the probability of assigning individuals to parent populations from the 5 sampled populations. The program was run using the admixture model that assumes all individuals potentially have mixed ancestry and assigns each individual to a designated population $(K)$. Twenty independent runs, incorporating burn-ins of $10^{5} \mathrm{MCMC}$ replicates followed by $10^{6}$ replicates of data collection, were performed with admixture model program defaults for $K$ values fixed at 1 to 6 populations. The probability of recent immigration to each population was fixed at $5 \%$. The rate of change in the log probability between successive $K$ values $(\Delta K)$ was calculated as in Evanno et al. (2005).

\section{RESULTS \\ mtDNA}

A $343 \mathrm{bp}$ fragment from the control region was analyzed for 140 individuals obtained from 14 locations (Fig. 1) spanning most of the geographical range of Pomacentrus coelestis. The nucleotide composition was $34.3 \% \mathrm{~A}, 33.0 \% \mathrm{~T}, 17.3 \% \mathrm{C}$, and $15.4 \%$ G. The ratio between transitions and transversions was $4.83: 1$. In total, 72 variable sites and 40 parsimoniously informative sites were found. Among the 140 individuals sequenced, 70 unique haplotypes were identified (Table 1). The nucleotide diversity $(\pi)$ ranged from $0.0005 \pm 0.0008$ to $0.0489 \pm 0.0294$ (mean $\pm \mathrm{SD}$ ), and haplotype diversity (h) ranged from $0.1538 \pm 0.1261$ to $1.0000 \pm 0.2722$ among localities.

The phylogenetic analysis resulted in 2 main clades, with 1 being strongly supported (96/0.99 NJ/Bayesian support) and consisting of 3 sub-clades. The basal sub-clade contained 2 haplotypes from Waigeo Island (WA), Bali Island (BA), and Kawe (KA) (colored orange in Fig. 2). Two derived sub-clades also had strong statistical support (88/0.9 and 78/0.95, respectively). One contained haplotypes from Kofiau Island (KO), KA, and Cenderawasih Bay (CE) (white in Fig. 2), while the other derived sub- 
clade (black in Fig. 2) contained haplotypes from the Micronesia region. The other main clade consisted of haplotypes from the West Pacific, including Japan, Taiwan, Brunei, Australia, and Fiji (blue in Fig. 2). To further support these results, partial mitochondrial cytochrome $c$ oxidase subunit I (COI) was amplified from a subset of 4 colored clades and closely related species $P$. auriventris by R2 and F2 primers (Ward et al. 2005). The topology of the phylogenetic tree based on the combination of the control region and COI (Fig. S1 in the supplement, available at www. int-res.com/articles/suppl/m458p155_supp.pdf) was similar to the tree shown in Fig. 2. The genetic divergence between clades is presented in Table S1 in the supplement.

The general topology of the minimum spanning tree corresponded with the NJ tree and revealed 4 clearly separated clades separated by 6, 10, and 18 mutation steps. Fifty-two haplotypes (blue in Fig. 3b) showed multiple star-like branches and were found widely across the West Pacific, including Taiwan, Japan, Brunei, Australia, Fiji, and parts of Raja Ampat (Indonesia). The remaining haplotypes fell

Fig. 2. Pomacentrus coelestis. Neighbor-joining phylogenic tree based on mtDNA control region haplotypes. Numbers above nodes represent support based on 1000 bootstrap replicates, and numbers below nodes represent clade credibility values from Bayesian analysis. The scale bar represents 0.02 nucleotide changes. The first color bar indicates 4 major clades, denoted in blue, orange, white, and black, and the second bar indicates 2 major groupings, denoted in red and green. Abbreviations as in Table 1

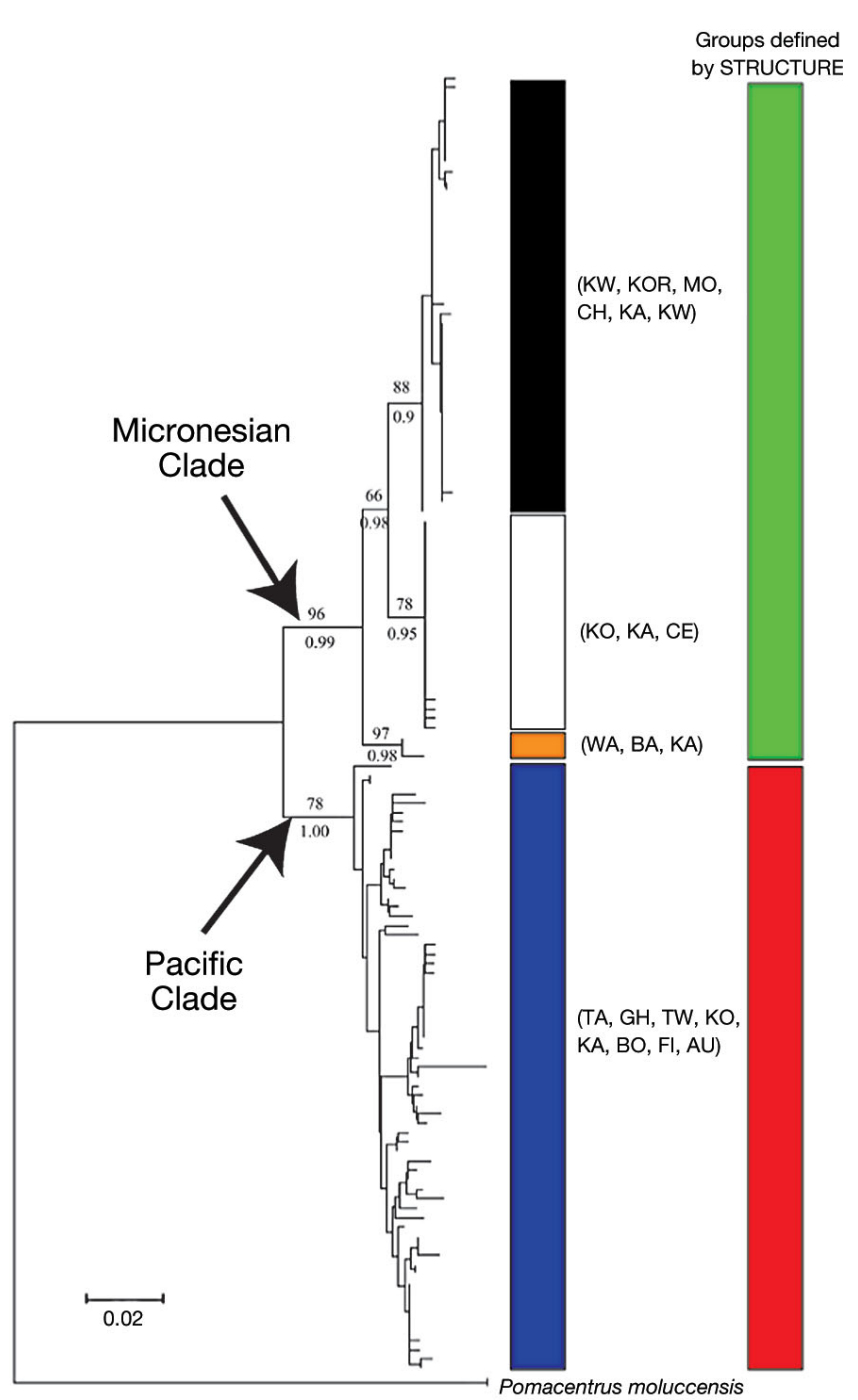

Table 1. Pomacentrus coelestis. Diversity of mtDNA control region of 15 populations from the West Pacific. Sites, site abbreviations (abb.), number of individuals $(\mathrm{N})$, number of haplotypes, haplotype diversity $(h \pm \mathrm{SD})$, and nucleotide diversity $(\pi \pm \mathrm{SD})$ are presented

\begin{tabular}{|llrcrc|}
\hline Site & Abb. & N & No. haplotypes & $h$ & $\pi$ \\
\hline Tanegashima Island, Japan & TA & 5 & 4 & $0.9000 \pm 0.1610$ & $0.0094 \pm 0.0068$ \\
Guihou, Taiwan & GU & 25 & 18 & $0.9433 \pm 0.0366$ & $0.0126 \pm 0.0072$ \\
Two Fat Thom, Brunei & TW & 8 & 8 & $1.0000 \pm 0.0625$ & $0.0149 \pm 0.0092$ \\
Fiji & FI & 3 & 3 & $1.0000 \pm 0.2722$ & $0.0254 \pm 0.0202$ \\
Capricorn/Bunker, Australia & AU & 17 & 12 & $0.9167 \pm 0.0643$ & $0.0107 \pm 0.0064$ \\
Bali, Indonesia & BA & 1 & 1 & - & - \\
Kofiau Island, Indonesia & KO & 10 & 5 & $0.6667 \pm 0.1633$ & $0.0261 \pm 0.0149$ \\
Kawe Island, Indonesia & KA & 7 & 7 & $1.0000 \pm 0.0962$ & $0.0489 \pm 0.0294$ \\
Boo Kecil, Indonesia & BO & 3 & 3 & $1.0000 \pm 0.2722$ & $0.0098 \pm 0.0085$ \\
Waigeo Island, Indonesia & WA & 6 & 3 & $0.7333 \pm 0.1552$ & $0.0115 \pm 0.0078$ \\
Cenderawasih Bay, Indonesia & CE & 13 & 2 & $0.1538 \pm 0.1261$ & $0.0005 \pm 0.0008$ \\
Kwajalein Atoll, Marshall Island & KW & 10 & 5 & $0.6667 \pm 0.1633$ & $0.0028 \pm 0.0024$ \\
Chuuk Atoll & CH & 11 & 4 & $0.7455 \pm 0.0978$ & $0.0034 \pm 0.0027$ \\
Koror, Palau & KOR & 14 & 6 & $0.6813 \pm 0.1316$ & $0.0033 \pm 0.0026$ \\
Mortlock Island, Chuuk state & MO & 7 & 3 & $0.7143 \pm 0.1267$ & $0.0025 \pm 0.0023$ \\
Total & & 140 & 70 & & \\
\hline
\end{tabular}


a
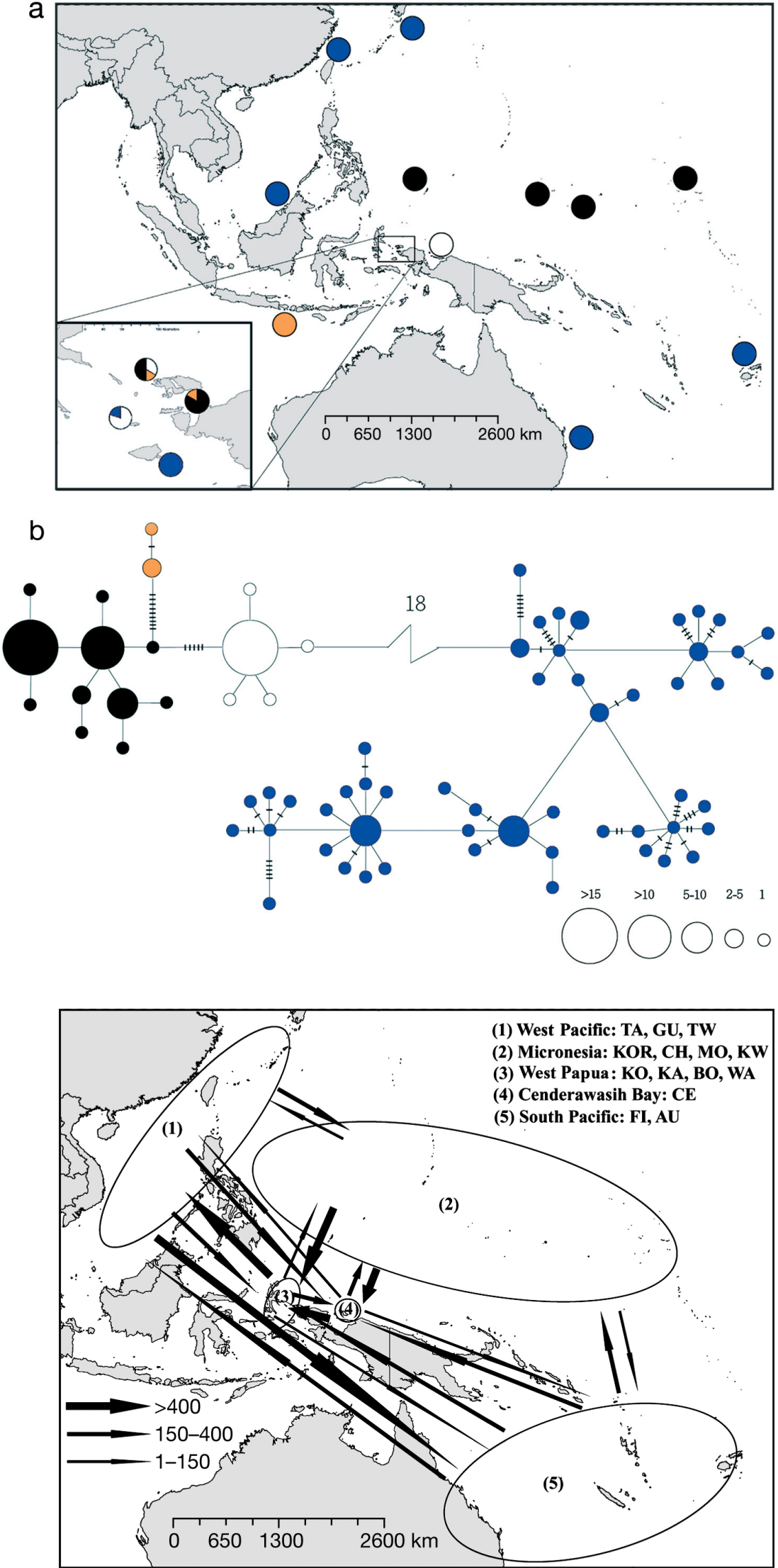

Fig. 3. Pomacentrus coelestis. (a) Study area with pie charts representing relative frequencies of each clade cluster in each site. (b) Minimum spanning tree of 70 haplotypes. The 4 colors correspond to the 4 subclades found in the phylogenetic tree (Fig. 2); circles are sized proportionally to the frequency of occurrence. All haplotypes are separated by 1 mutational step unless denoted by additional hatch marks

into 3 clades, arbitrarily labeled black, white, and orange. The black clade was mainly found in Micronesia, although it also appeared in populations in the Raja Ampat Islands. The Cendrawasih Bay population was comprised exclusively of the white clade, although these haplotypes also appeared in low numbers in some Raja Ampat populations. Finally, orange haplotypes were found in Bali and the Raja Ampat Islands. The high heterogeneity of the Raja Ampat populations is of particular interest and is discussed in more detail below.

Due to the small sample size at some sites $(\mathrm{n}<5$ : Fiji, FI; and Boo Kecil, Indonesia, BO), we divided the sampling sites into 5 groups (Fig. 4) based on geographical locations to measure bi-directional gene flow with MIGRATE. The results indicated relatively low larval exchange between the Micronesian and West Pacific groups, and between the South Pacific and the Cenderawasih Bay populations. Higher larval exchange was found between the West and South Pacific populations, and also between the Micronesia, Cenderawasih Bay, and Raja Ampat Islands

Fig. 4. Pomacentrus coelestis. Study area with migration patterns estimated using MIGRATE based on mtDNA control region haplotypes. Arrows show the directionality of gene flow, with associated estimates of the number of effective migrants per generation $\left(\mathrm{N}_{\mathrm{e}}\right)$. Arrow thickness indicates the relative strength of gene flow. The exact $\mathrm{N}_{\mathrm{e}}$ values are given in Table S2 in the supplement (at www.int-res.com/articles/suppl/ m458p155_supp.pdf) 
Table 2. Pomacentrus coelestis. Hierarchical analysis of molecular variance $(\Phi)$ within and among 14 populations in the West Pacific based on the mtDNA control region. In Scenario $\mathrm{A}$, populations were grouped to allow examination of geographic partitioning. West Pacific included TA, GU, and TW; South Pacific included FI and AU; West Papua included $\mathrm{CE}, \mathrm{KO}, \mathrm{KA}, \mathrm{BO}$, and $\mathrm{WA}_{\text {; }}$ and Micronesia included $\mathrm{KW}, \mathrm{CH}$, $\mathrm{PA}$, and MO (abbreviations are defined in Table 1). In Scenario $B$, populations were grouped based on the partition of the phylogenetic tree (Fig. 2). Bali samples were not included in either tests due to small sample size $(\mathrm{n}=1) .{ }^{* *} \mathrm{p}<0.01$

\begin{tabular}{|llcc|}
\hline Scenario & Source of variance & $\begin{array}{c}\% \text { total } \\
\text { variance }\end{array}$ & $\Phi$ \\
\hline (A) West Pacific, & Among regions & 68.17 & $0.682^{* *}$ \\
$\begin{array}{l}\text { South Pacific, } \\
\text { West Papua, }\end{array}$ & Among populations/ & 12.13 & $0.381^{* *}$ \\
Micronesia & Within regions & & \\
$\begin{array}{l}\text { (B) Pacific clade, } \\
\text { Micronesia } \\
\text { clade }\end{array}$ & Among regions & 75.21 & $0.752^{* *}$ \\
& Among populations/ & 9.10 & $0.367^{* *}$ \\
& within regions & 19.70 & $0.803^{* *}$ \\
& & 15.69 & $0.843^{* *}$ \\
\hline
\end{tabular}

populations (Fig. 4). The results of the AMOVA comparisons of genetic variation within and between the West Pacific, the South Pacific, West Papua, and Micronesian populations revealed that $68 \%$ of the variance was among regions, and significant genetic differentiation was found at all 3 comparison levels $(p<0.01)$. However, when we assigned all haplotypes into 2 groups based on the partitions of the NJ tree (Fig. 3a), the proportion of variance among the groups rose to $75 \%$ (Table 2). In addition, we used the same haplotype grouping (Pacific and Micronesian clades) to perform neutrality tests, mismatch analyses, and expansion time estimations. Among the 2 tests of neutrality, Tajima's $D$ and Fu's Fs values of the Pacific group were both negative and departed from the neutral state. On the other hand, although the Tajima's $D$ and Fu's $F$ s values of the Micronesian group were negative, both tests were non-significant (Table 3).

A mismatch distribution test on both the Pacific and Micronesian groups failed to reject the hypothesis of the sudden expansion model (Fig. 5). Parameters generated from mismatch analyses were then used to

Table 3. Pomacentrus coelestis. Results of Tajima's D and Fu's Fs neutrality tests for the Micronesian and Pacific clades. ${ }^{*} \mathrm{p}<0.05 ;{ }^{* *} \mathrm{p}<0.01$

\begin{tabular}{|llc|}
\hline Group & Tajima's $D$ & Fu's Fs \\
\hline Micronesian clade & -0.29048 & -2.14536 \\
Pacific clade & $-1.80182^{*}$ & $-25.4832^{* *}$ \\
\hline
\end{tabular}

estimate time to coalescence. The estimation of mutation rates of the 5' portion of the mitochondrial control region in bony fish varies among species due to the paucity of fish fossils. In the damselfish Chromis chromis, the estimated mutation rate ranges from 8.2 to $9.3 \%$ per million years (Myr) (Domingues et al. 2005). The $\tau$ values of the Pacific and Micronesian haplotype groups were 4.787 and 9.477 , respectively. The time since population expansion of the Pacific haplotype group was about 0.075 to 0.086 yr before present, and approximately $0.149 \mathrm{M}$ to $0.170 \mathrm{Myr}$ before present for the Micronesian group.

\section{Microsatellite loci}

Of the 140 DNA samples, 133 were successfully amplified with 4 microsatellite loci primer sets. All 4 loci were polymorphic, with 17 to 91 alleles segregating per locus across the 3 groups of populations. Observed heterozygosity ranged from 0.6 to 0.891 , and most showed significant heterozygote deficiency

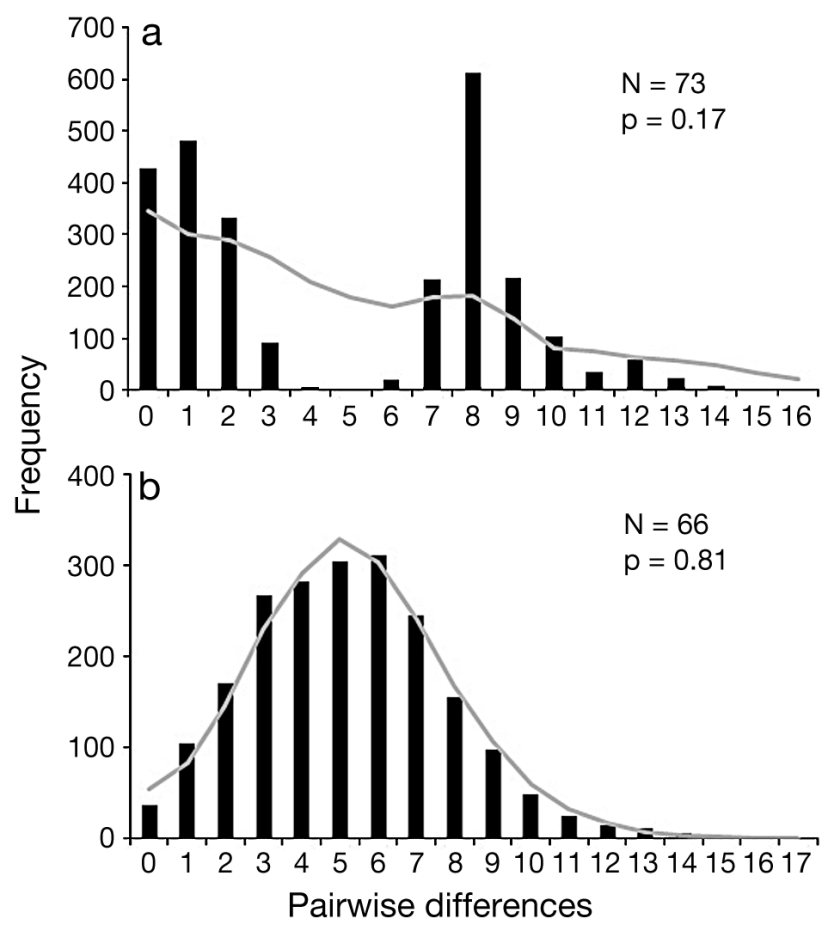

Fig. 5. Pomacentrus coelestis. Mismatch distributions for the (a) Micronesian and (b) Pacific haplotype groups (Fig. 2) based on mtDNA control region haplotypes. Observed pairwise differences are shown as black bars. The expected distribution under the expansion model is represented by the gray curve. The number of individuals sequenced $(\mathrm{N})$ and the p-value of the associated goodness-of-fit test are presented for each distribution 
Table 4. Pomacentrus coelestis. Microsatellite data comparing the number of alleles (A), sample size $(\mathrm{N})$, and observed and expected heterozygosity ( $H_{\mathrm{o}}$ and $H_{\mathrm{e}}$, respectively) among 3 groups. Groups were based on the haplotype distribution in Fig. 3a. Abbreviations of localities are given in Table 1. The Pacific group included TA, GU, TW, FI, and AU. The Raja Ampat group included KO, KA, BO, and WA. The Micronesian group included $\mathrm{KW}, \mathrm{CH}, \mathrm{CE}, \mathrm{PA}$, and MO. ${ }^{*} \mathrm{p}<0.05 ;{ }^{* *} \mathrm{p}<0.01$

\begin{tabular}{|lccccc|}
\hline \multirow{2}{*}{ Locus } & \multirow{2}{*}{$\mathrm{A}$} & & \multicolumn{3}{c|}{ Group } \\
\cline { 4 - 6 } & & & Micronesia & Raja Ampat & Pacific \\
\hline \multirow{2}{*}{ POM3 } & \multirow{2}{*}{26} & $\mathrm{~N}$ & 55 & 20 & 58 \\
& & $\mathrm{~A}$ & 23 & 11 & 20 \\
& & $H_{\mathrm{o}}$ & $0.691^{* *}$ & $0.6^{* *}$ & 0.759 \\
& & $H_{\mathrm{e}}$ & $0.888^{*}$ & 0.904 & 0.831 \\
POM25 & 77 & $\mathrm{~N}$ & 55 & 20 & 58 \\
& & $\mathrm{~A}$ & 54 & 25 & 30 \\
& & $H_{\mathrm{o}}$ & $0.891^{* *}$ & 0.8 & $0.776^{* *}$ \\
& & $H_{\mathrm{e}}$ & 0.983 & 0.963 & 0.905 \\
AC1578 & 17 & $\mathrm{~N}$ & 55 & 20 & 58 \\
& & $\mathrm{~A}$ & 13 & 9 & 14 \\
& & $H_{\mathrm{o}}$ & 0.891 & 0.8 & $0.724^{* *}$ \\
& & $H_{\mathrm{e}}$ & 0.874 & 0.832 & 0.81 \\
POM6 & 91 & $\mathrm{~N}$ & 55 & 20 & 58 \\
& & $\mathrm{~A}$ & 55 & 31 & 38 \\
& & $H_{\mathrm{o}}$ & $0.873^{* *}$ & $0.75^{*}$ & $0.776^{*}$ \\
& & $H_{\mathrm{e}}$ & 0.984 & 0.976 & 0.964 \\
\hline
\end{tabular}

populations. Most of the populations had high haplotype diversity and low nucleotide diversity, which might be attributed to a rapid expansion of the population after a period of low population density (Grant \& Bowen 1998). This diversity pattern is commonly found in reef fishes which lose their habitat during glacial-induced sea level fluctuations (Domingues et al. 2006, Liu et al. 2008, Timm \& Kochzius 2008), as has been proposed for fish populations in Cenderawasih Bay (Allen \& Erdmann 2006, Allen 2008). However, Cenderawasih Bay was the only population harboring extremely low haplotype $(0.1538 \pm 0.1261)$ and nucleotide $(0.0005 \pm 0.0008)$ diversity, indicating that the population may have suffered a recent bottleneck or founder event (Grant \& Bowen 1998). Previous phylogeographic studies of various marine taxa have also found unique genetic diversity in the Cenderawasih Bay region (Barber et al. 2006, Crandall et al. 2008, Nuryanto \& Kochzius 2009). Allen \& Erdmann (2006) hypothesized that the bay was essentially isolated for substantial periods over the

(Table 4). Tests of genotypic disequilibrium between loci were also non-significant, supporting independent assortment of these microsatellite loci.

To test the mixed mtDNA lineages found in the Raja Ampat area, the admixture model was implemented by STRUCTURE 2.3 and returned the highest posterior likelihood probability for 2 populations $(K=2)$ under a 3-group partition. We used $90 \%$ as a threshold for segregating individuals between Micronesian and Pacific populations; individuals higher than $90 \%$ were assigned to the Micronesian group (green in Fig. 6) and those less than 90\% to the Pacific group (red). Interestingly, populations from the Raja Ampat Islands contained individuals assigned to both groups, which is concordant with the results found in mtDNA analyses.

\section{DISCUSSION}

\section{Genetic diversity}

High levels of polymorphism and genetic diversity were observed in the sampled Pomacentrus coelestis

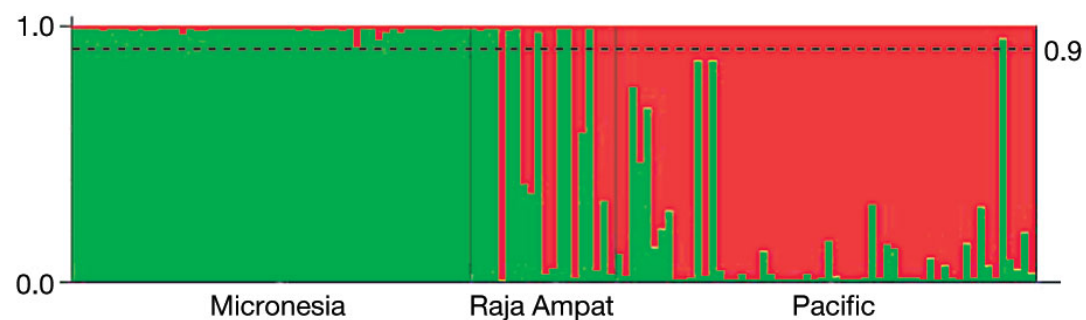

Fig. 6. Pomacentrus coelestis. Bayesian population structure from microsatellite data indicating the parent population $(K=2)$. Individual probabilities of assignment are shown on the $y$-axis and are grouped by parental populations calculated by the admixture program in STRUCTURE 2.3. A threshold of $90 \%$ was set to assign individuals to green $(>90 \%)$ or red $(<90 \%)$ parent populations. Three different groups of populations were used to perform this Bayesian assignment. Group compositions are given in Table 4 


\section{Phylogeographic relationships}

Our phylogenetic analysis generated 2 statistically supported, monophyletic clades, separated by 18 mutational steps on a minimum spanning tree. Populations of Pomacentrus coelestis from Japan and Palau are actually distinct species based on allozyme variation (Lacson 1994). This result is supported by the present study, which shows that the 2 populations belong to different monophyletic clades. The Bayesian assignment test determined the same grouping as the phylogenetic analysis. Therefore, we defined both a 'Pacific' clade including blue haplotypes, and a 'Micronesian' clade consisting of orange, white, and black haplotypes (Fig. 2). The latter group contained 3 sub-clades characterized by a northeastward cladogenesis. The basal clade was formed in Indonesia with subsequent movement towards eastern peripheral populations in Micronesia, supporting the stepping stone dispersal model (Palumbi 1996).

The haplotypes of the Pacific clade are widely distributed across the West Pacific (Fig. 3a, blue haplotypes), but exhibit a typical, shallow genetic architecture (Fig. 2) with no ability to discern dispersal direction. This pattern might be due to constant gene flow or incomplete lineage sorting. Although Pomacentrus coelestis has a pelagic larval duration of approximately $20 \mathrm{~d}$ (Thresher et al. 1989), it is unlikely to disperse over such a great distance of open water as is represented by the blue clade's distribution range $(6300 \mathrm{~km})$ in a single generation. Moreover, during Pleistocene glacial periods, the Sunda Shelf and Java Sea formed land barriers repeatedly due to sea level changes (Voris 2000), and loss of habitat in the region would have decreased the chance that propagules could find suitable habitat. Therefore, we suggest that the populations in this clade might have expanded after a glacial retreat, with insufficient time for lineage sorting.

In addition to the comparisons of genetic differentiation between the Pacific and Micronesian clades of Pomacentrus coelestis, we also analyzed a closely related species, the gold-belly damselfish $P$. auriventrus, which is clearly differentiated from $P$. coelestis on the basis of color pattern with a subset of COI sequences. The pairwise genetic distance (Kimura 2parameter distance) between the 2 morphologically identical clades of $P$. coelestis (0.04) is higher than that between the Pacific clade and $P$. auriventrus (0.015; Table S1). Steinke et al. (2009) suggested that lineages showing more than $2 \%$ divergence of COI likely represent overlooked species. Based on this threshold, we suggest that these 2 clades could be considered as sibling species. Further meristic studies need to be conducted to describe the Micronesian clade as a new species.

\section{Demographic history}

The haplotypes of the main clades of Pomacentrus coelestis, representing 2 distinct lineages, were used to perform neutrality tests. The results showed that only the Pacific clade, which demonstrated a star-like haplotype network (Fig. 3), departed from the neutral state (Table 3), suggesting sudden population expansion in the past. The results of the mismatch distribution tests were congruent with the expansion model, but the distribution patterns of the 2 clades were completely different. The Pacific clade formed a unimodal distribution, indicating rapid population growth, while the Micronesian clade formed a multimodal pattern, suggesting that the population was at demographic equilibrium (Fig. 5). Moreover, the estimated expansion time based on coalescence theory suggested that the Micronesian clade expanded much earlier (0.149 to 0.170 Myr ago) than the Pacific clade (0.075 to 0.086 Myr ago), indicating different demographic histories.

\section{Population structure and connectivity}

The migration rates generated by MIGRATE were based on the pairwise sequence variations of the coalescence theory. Closely related species can have larval exchange values $>0$, even if reproductive isolation has already occurred. In the present study, we used these values to infer population structure among populations. The relatively small amount of larval exchange between the Micronesian and Pacific groups of Pomacentrus coelestis supports the existence of the 2 clades found in the phylogenetic tree (Fig. 2). In addition, the hierarchical AMOVA and Bayesian genotyping data showed the same pattern, indicating a major genetic break between the Micronesian and Pacific groups (Table 2, Fig. 6). Finally, moderate gene flow between the Micronesian, Cenderawasih Bay, and Raja Ampat groups was observed (Fig. 4). These 3 populations might be connected via the New Guinea Coastal Current (NGCC), which flows northeastwardly towards Micronesia from the western end of New Guinea during the southern summer (Schiller et al. 2008). The presence of large islands 
or island groups in the outer half of Cenderawasih Bay might at least partially shield the bay from eastward flowing currents, retarding larval recruitment during this same period (Allen \& Erdmann 2006). We suggest that some of the larvae with white haplotypes (mainly found in Cenderawasih Bay; Fig. 3b) may, however, disperse westwardly towards Raja Ampat when the NGCC reverses direction seasonally and flows westerly across the top of the Bird's Head Peninsula, which would explain the occurrence of white haplotypes at the Raja Ampat Islands. Moderate gene flow was also noted between the Raja Ampat Islands and the West Pacific, South Pacific, and Micronesian groups (Fig. 4). This could be a consequence of mixed haplotype groups at the Raja Ampat Islands, thus increasing the genetic similarity between the groups (Fig. 3a).

\section{Origin of Pomacentrus coelestis}

Studies of population structure and phylogeography in the West Pacific have drawn different conclusions concerning the center of biodiversity. Most of the past research supports the Center of Origin hypothesis (Barber et al. 2006, Williams 2007, Timm \& Kochzius 2008, Nuryanto \& Kochzius 2009). In contrast, relatively few cases substantiate the Center of Overlap (Teske et al. 2005, Gaither et al. 2011) and Center of Accumulation hypotheses (Wilson et al. 2001, Drew \& Barber 2009). Barber (2009) suggested that the central West Pacific's diversity is likely the result of multiple evolutionary processes, working either simultaneously or over different time periods, being dominated by different processes.

The present study of genetic divergence between the Pacific and Micronesian clades suggests that the interpretation of their origins should be conducted separately. Within the Pacific clade, the sequence variations lack sufficient information that would enable us to infer an origin due to a recent, rapid population expansion. However, the Micronesian clade displayed a clear trend indicative of a West Pacific origin, later moving outward towards peripheral areas. Therefore, the suggested dispersal direction would appear to agree with the Center of Origin hypothesis. The Raja Ampat populations, which harbor mixed lineages (Fig. 3a), might also indicate a correlation with the Center of Overlap hypothesis.

The Center of Overlap hypothesis originated from the idea that tectonic movements created overlapping zones of different biogeographic provinces
(Woodland 1983), leading to the mixed evolutionary lineages found today. However, this process requires tens of millions years to evolve (Springer 1982). Thus, the mixed lineages of Pomacentrus coelestis occurring at the Raja Ampat Islands apparently are not the result of this process, but were likely formed during the Pleistocene (expansion time of the Micronesian clade: 148540 to 170280 years). Pleistocene sea level fluctuations may have caused several vicariance events, thus initiating fish speciation (Rocha \& Bowen 2008). Our results suggest that after the major clades were formed, each lineage gradually expanded its distribution. A contributing factor that possibly helps to explain the extraordinary diversity of the Raja Ampat Islands, as well as the greater West Pacific, is that it encompasses the distributional boundaries of a multitude of mixed lineages, similar to that shown for $P$. coelestis in the present study. Certainly these mixed lineages could be the result of both tectonic activity and dispersal following population subdivision.

Populations within a single 'species' that actually involve more than 1 taxon are common among marine organisms (Knowlton 1993). Multiple species that possess similar morphology, yet are genetically distinct, are particularly problematical when allele distribution is used to infer species origin. For example, in the present study, fish belonging to separate clades have identical morphology, but different evolutionary histories. If considered as a single species based on morphological features alone, inferences regarding origin may be misleading. Therefore, a broad-scale, comparative, phylogeographic study of closely related species is recommended. This will not only result in a better understanding of local populations and their potential for being recognized as separate species, but will also provide valuable clues regarding the origin of particular clades.

\section{Management implications}

Carpenter et al. (2010) reviewed invertebrate and fish phylogeography studies of the West Pacific and suggested the creation of 8 management units based on concordant phylogeographic breaks. Units 1 and 2 are separated by Sumatra, Unit 3 includes Java and the Lesser Sunda Islands, Unit 4 includes most of the seas east of Borneo, including Sulawesi, the Celebes Sea, and the Banda Sea, Unit 5 extends from Halmahera to the westernmost Bird's Head region of West Papua (including the Raja Ampat Islands), and Unit 6 contains the Cenderawasih Bay 
area of West Papua. The remaining 2 units are located in the northeastern and southeastern Philippines, separated by the North Equatorial Current. In our study, mtDNA and nuclear microsatellite loci indicated that there may be 2 sibling species within Pomacentrus coelestis. Therefore, with regards to conservation purposes, these 2 lineages need to be considered as 2 sibling species rather than a single species. One species (the true $P$. coelestis) contains all of the blue haplotypes, and the other species contains yellow, white, and black haplotypes (Fig. $3 b)$. Although we did not have any sampling sites in western and central Indonesia, the occurrence of blue haplotypes at the Raja Ampat Islands suggests that members of this lineage are distributed across the West Pacific, reaching its eastern boundary at Fiji. In contrast, the other species has a relatively restricted distribution and includes 3 haplotype groups. The yellow haplotype group is mainly found within Units 3, 4, and 5. The white haplotype is only found in Cenderawasih Bay and the Raja Ampat Islands, corresponding to Unit 6. However, Micronesia, where the black haplotype occurred, was not included in the review of Carpenter et al. (2010). Therefore, we suggest that the latter species should be managed as 3 units, with Micronesia considered as an additional management unit. Due to a lack of consistency in phylogeographic patterns in previous studies of reef fish (Carpenter et al. 2010), there is an urgent need for further studies featuring more comprehensive sampling from localities across the western Pacific to provide a much-needed baseline for future reef fish conservation in the region. The results of this study reveal possible origins of 2 sibling species within $P$. coelestis and denote areas that should be considered as separate management units by regional authorities.

Acknowledgements. We thank G. Gerlach (Zoodiversity and Evolution, Carl von Ossietzky University Oldenburg, Germany) for providing tissue samples from Australia. We are grateful to M. J. Ho and Y. R. Cheng for their assistance with fieldwork, as well as to A. Mayfield for critical commentary on the manuscript. We also thank the Paine Family Trust, D. Cohen, and W. Henry for financial support of the Indonesian fieldwork. This study was supported by a grant from the National Science Council of Taiwan ROC (NSC99-2811-M002-151) to C.F.D.

\section{LITERATURE CITED}

Allen GR (1991) Damselfishes of the world. Mergus Publishers, Melle

Allen GR (2008) Conservation hotspots of biodiversity and endemism for Indo-Pacific coral reef fishes. Aquat Conserv 18:541-556

Allen GR, Erdmann MV (2006) Cirrhilabrus cenderawasih, a new wrasse (Pisces: Labridae) from Papua, Indonesia. Aqua: J Ichthyol Aquat Biol 11:89-96

Barber PH (2009) The challenge of understanding the Coral Triangle biodiversity hotspot. J Biogeogr 36:1845-1846

- Barber PH, Erdmann MV, Palumbi SR (2006) Comparative phylogeography of three codistributed stomatopods: origins and timing of regional lineage diversification in the Coral Triangle. Evolution 60:1825-1839

Beerli P (2006) Comparison of Bayesian and maximum likelihood inference of population genetic parameters. Bioinformatics 22:341-345

> Beerli P, Felsenstein J (2001) Maximum likelihood estimation of a migration matrix and effective population sizes in $\mathrm{n}$ subpopulations using a coalescent approach. Proc Natl Acad Sci USA 98:4563-4568

Bellwood DR, Wainwright PC (2002) The history and biogeography of fishes on coral reefs. In: Sale PF (ed) Coral reef fishes: Dynamics and diversity in a complex ecosystem. Academic Press, San Diego, CA, p 5-32

Carpenter KE, Barber PH, Crandall ED, Ablan-Lagman MCA and others (2010) Comparative phylogeography of the Coral Triangle and implications for marine management. J Mar Biol 2011:1-14

> Connolly SR, Bellwood DR, Hughes TP (2003) Indo-Pacific biodiversity of coral reefs: deviations from a mid-domain model. Ecology 84:2178-2190

Crandall ED, Jones ME, Muñoz MM, Akinronbi B and others (2008) Comparative phylogeography of two seastars and their ectosymbionts within the Coral Triangle. Mol Ecol 17:5276-5290

Doherty PJ, Kingsford MJ, Booth D, Carleton J (1996) Habitat selection before settlement by Pomacentrus coelestis. Mar Freshw Res 47:391-399

> Domingues VS, Bucciarelli G, Almada VC, Bernardi G (2005) Historical colonization and demography of the Mediterranean damselfish, Chromis chromis. Mol Ecol 14:4051-4063

> Domingues VS, Santos RS, Brito A, Almada VC (2006) Historical population dynamics and demography of the eastern Atlantic pomacentrid Chromis limbata (Valenciennes, 1833). Mol Phylogenet Evol 40:139-147

> Drew J, Barber PH (2009) Sequential cladogenesis of the reef fish Pomacentrus moluccensis (Pomacentridae) supports the peripheral origin of marine biodiversity in the Indo-Australian archipelago. Mol Phylogenet Evol 53: 335-339

> Drew J, Allen G, Kaufman L, Barber PH (2008) Endemism and regional colour and genetic differences in five putatively cosmopolitan reef fishes. Conserv Biol 22: 965-975

Drew JA, Allen GR, Erdmann MV (2010) Congruence between mitochondrial genes and color morphs in a coral reef fish: population variability in the Indo-Pacific damselfish Chrysiptera rex (Snyder, 1909). Coral Reefs 29: 439-444

Ekman S (1953) Zoogeography of the sea. Sidgwick \& Jackson, London

- Evanno G, Regnaut S, Goudet J (2005) Detecting the number of clusters of individuals using the software STRUCTURE: a simulation study. Mol Ecol 14:2611-2620

- Excoffier L, Smouse PE, Quattro JM (1992) Analysis of molecular variance inferred from metric distances among 
DNA haplotypes: application of human mitochondrial DNA restriction data. Genetics 131:479-491

Excoffier L, Laval G, Schneider S (2005) Arlequin ver. 3.0: an integrated software package for population genetics data analysis. Evol Bioinform Online 1:47-50

Fisher R (2005) Swimming speeds of larval coral reef fishes: impacts on self-recruitment and dispersal. Mar Ecol Prog Ser 285:223-282

Fu YX (1996) New statistical tests for DNA samples from a population. Genetics 143:557-570

Fu YX, Li WH (1993) Statistical tests of neutrality of mutation. Genetics 133:693-709

> Gaggiotti OE, Excoffier L (2000) A simple method of removing the effect of a bottleneck and unequal population sizes on pairwise genetic distances. Proc Biol Sci 267: 81-87

> Gaither MR, Bowen BW, Bordenave TR, Rocha LA and others (2011) Phylogeography of the reef fish Cephalopholis argus (Epinephelidae) indicates Pleistocene isolation across the Indo-Pacific barrier with contemporary overlap in the Coral Triangle. BMC Evol Biol 11:189

Gerlach G, Atema J, Kingsford MJ, Black KP, Miller-Sims V (2007) Smelling home can prevent dispersal of reef fish larvae. Proc Natl Acad Sci USA 104:858-863

Grant WS, Bowen BW (1998) Shallow population histories in deep evolutionary lineages of marine fishes: insight from sardines and anchovies and lessons for conservation. J Hered 89:415-426

Guo SW, Thompson EA (1992) Performing the exact test of Hardy-Weinberg proportion for multiple alleles. Biometrics 48:361-372

Hellberg ME, Burton RS, Neigel JE, Palumbi SR (2002) Genetic assessment of connectivity among marine populations. Bull Mar Sci 70:273-290

Holt RD (2003) On the evolutionary ecology of species' ranges. Evol Ecol Res 5:159-178

Knowlton N (1993) Sibling species in the sea. Annu Rev Ecol Evol Syst 24:189-216

Knowlton N (2000) Molecular genetic analyses of species boundaries in the sea. Hydrobiologia 420:73-90

> Lacson JM (1994) Fixed allele frequency differences among Palauan and Okinawan populations of the damselfishes Chrysiptera cyanea and Pomacentrus coelestis. Mar Biol 118:359-365

> Lee WJ, Conroy J, Howell WH, Kocher TD (1995) Structure and evolution of teleost mitochondrial control regions. J Mol Evol 41:54-66

> Liu SYV, Dai CF, Yu HT (2005) Cloning and characterization of microsatellite loci in a gorgonian coral, Junceella juncea (Anthozoa; Octocorallia; Ellisellidae) and its application in clonal genotyping. Mar Biotechnol 7: 26-32

> Liu SYV, Yu HT, Dai CF (2007) Eight microsatellite loci in Clark's anemonefish Amphiprion clarkii. Mol Ecol Notes 7:1169-1171

Liu SYV, Kokita T, Dai CF (2008) Population genetic structure of the neon damselfish (Pomacentrus coelestis) in the northwestern Pacific Ocean. Mar Biol 154:745-753

Malay MC, Paulay G (2010) Peripatric speciation drives diversification and distributional pattern of reef hermit crabs (Decapoda: Diogenidae: Calcinus). Evolution 64: 634-662

Miller-Sims V, Atema J, Kingsford MJ, Gerlach G (2005) DNA microsatellites in the neon damselfish (Pomacentrus coelestis). Mol Ecol Notes 5:424-426
Mora C, Chittaro PM, Sale PF, Kritzer JP, Ludsin SA (2003) Patterns and processes in reef fish diversity. Nature 421: 933-936

Nuryanto A, Kochzius M (2009) Highly restricted gene flow and deep evolutionary lineages in the giant clam Tridacna maxima. Coral Reefs 28:607-619

Palumbi SR (1994) Genetic divergence, reproductive isolation, and marine speciation. Annu Rev Ecol Evol Syst 25: $547-572$

Palumbi SR (1996) What can molecular genetics contribute to marine biogeography? An urchin's tale. J Exp Mar Biol Ecol 203:75-92

Paulay G (1996) Dynamic clams: changes in the bivalve fauna of Pacific islands as a result of sea level fluctuations. Am Malacol Bull 12:45-57

Paulay G, Meyer C (2002) Diversification in the tropical Pacific: comparisons between marine and terrestrial systems and the importance of founder speciation. Integr Comp Biol 42:922-934

> Pritchard JK, Stephens M, Donnelly PJ (2000) Inference of population structure using multilocus genotype data. Genetics 155:945-959

Raymond M, Rousset F (1995) Genepop (version 1.2), population genetics software for exact tests and ecumenicism. J Hered 86:248-249

Roberts CM, McClean CJ, Veron JEN, Hawkins JP and others (2002) Marine biodiversity hotspots and conservation priorities for tropical reefs. Science 295:1280-1284

Rocha LA, Bowen BW (2008) Speciation in coral reef fishes. J Fish Biol 72:1101-1121

Ronquist F, Huelsenbeck JP (2003) MrBayes 3: Bayesian phylogenetic inference under mixed models. Bioinformatics 19:1572-1574

Rosen BR (1988) Progress, problems and patterns in the biogeography of reef corals and other tropical marine organisms. Helgol Mar Res 42:269-301

Schiller A, Oke PR, Brassington G, Entel M, Fiedler R, Griffin DA, Mansbridge JV (2008) Eddy-resolving ocean circulation in the Asian-Australian region inferred from an ocean reanalysis effort. Prog Oceanogr 76:334-365

Slatkin M, Hudson RR (1991) Pairwise comparisons of mitochondrial DNA sequences in stable and exponentially growing populations. Genetics 129:555-562

Springer VG (1982) Pacific plate biogeography, with special reference to shorefishes. Smithson Contrib Zool 367: $1-182$

Steinke D, Zemlak TS, Hebert PDN (2009) Barcoding Nemo: DNA-based identifications for the ornamental fish trade. PLoS One 4:e6300

- Tamura K, Dudley J, Nei M, Kumar S (2007) MEGA4: Molecular Evolutionary Genetics Analysis (MEGA) software version 4.0. Mol Biol Evol 24:1596-1599

> Teske PR, Hamilton H, Palsbøll PJ, Choo CK and others (2005) Molecular evidence for long distance-colonization in an Indo-Pacific seahorse lineage. Mar Ecol Prog Ser 286:249-260

Thompson JD, Higgins DG, Gibson TJ (1994) CLUSTAL W: improving the sensitivity of progressive multiple sequence alignment through sequence weighting, position specific gap penalties and weight matrix choice. Nucleic Acids Res 22:4673-4680

- Thresher RE, Colin PL, Bell LJ (1989) Planktonic duration, distribution and population structure of western and central Pacific damselfishes (Pomacentridae). Copeia 1989: 420-434 
Timm J, Kochzius M (2008) Geological history and oceanography of the Indo-Malay Archipelago shape the genetic population structure in the false clown anemonefish (Amphiprion ocellaris). Mol Ecol 17: 3999-4014

Veron JEN (2000) Corals of the world. AIMS, Townsville

Voris HK (2000) Maps of Pleistocene sea levels in Southeast Asia: shorelines, river systems and time durations. J Biogeogr 27:1153-1167

Ward RD, Zemlak TS, Innes BH, Last PR, Hebert PDN (2005) DNA barcoding of Australia's fish species. Philos Trans R Soc Lond B Biol Sci 360:1847-1857

Editorial responsibility: Philippe Borsa, Montpellier, France
Williams ST (2007) Origins and diversification of Indo-West Pacific marine fauna: evolutionary history and biogeography of turban shells (Gastropoda, Turbinidae). Biol J Linn Soc 92:573-592

Wilson AB, Vincent A, Ahnesjö I, Meyer A (2001) Male pregnancy in seahorses and pipefishes (Family Syngnathidae): rapid diversification of paternal brood pouch morphology inferred from a molecular phylogeny. J Hered 92:159-166

Woodland DJ (1983) Zoogeography of the Siganidae (Pisces): an interpretation of distribution and richness patterns. Bull Mar Sci 33:713-717

Submitted: September 16, 2011; Accepted: January 31, 2012 Proofs received from author(s): June 21, 2012 